\title{
Productivity collapses in the Arabian Sea during glacial cold phases
}

\author{
Arun Deo Singh, ${ }^{1}$ Simon J. A. Jung, ${ }^{2}$ Kate Darling, ${ }^{2}$ Raja Ganeshram, ${ }^{2}$ Tara Ivanochko, ${ }^{3}$ \\ and Dick Kroon ${ }^{2}$ \\ Received 29 December 2009; revised 15 April 2011; accepted 5 May 2011; published 3 August 2011.
}

[1] Productivity in the Arabian Sea is one of the highest in the world. It is controlled by seasonally reversing monsoonal wind-driven upwelling of nutrient-rich deeper waters which fuel phytoplankton growth. The detailed history of upwelling-induced productivity in the eastern Arabian Sea is unknown. Here we present paleoproductivity records from a composite sediment core at the millennial scale during the last $80 \mathrm{kyr}$ B.P. These records are based on relative abundance counts of planktonic foraminifera and organic carbon contents, which are shown to mainly vary in concert. The eastern Arabian Sea upwellinginduced productivity was higher in the glacial period than in the Holocene, but it fell repeatedly on millennial timescales. These productivity declines occurred during cold events in the North Atlantic region, with the most pronounced changes prevailing during the Heinrich events. Hence, seasonal monsoon winds that drive upwelling-induced productivity in the east were weak when the North Atlantic was cold. These weak winds resulted in stratification of the water column, comparable to today's Arabian Sea stratification in the intermonsoonal period. Combining the new eastern with published western Arabian Sea results shows that the entire biological factory was severely diminished during the North Atlantic Heinrich events, and the seasonal productivity change in the Arabian Sea monsoon system was reduced with year-round low productivity.

Citation: Singh, A. D., S. J. A. Jung, K. Darling, R. Ganeshram, T. Ivanochko, and D. Kroon (2011), Productivity collapses in the Arabian Sea during glacial cold phases, Paleoceanography, 26, PA3210, doi:10.1029/2009PA001923.

\section{Introduction}

[2] In the Arabian Sea, seasonally reversing Indian southwest (SW; summer) and northeast (NE; winter) monsoon winds exert a profound influence on biological productivity (Figure 1), making it one of the world's most fertile areas [Banse and McClain, 1986; Bauer et al., 1991]. Today productivity patterns show temporal and spatial heterogeneity linked to SW and NE monsoon winds (Figure 1). SW monsoon winds cause large-scale upwelling during summer in the western and northern Arabian Sea [Colborn, 1975; Wyrtki, 1974] which fuel intense phytoplankton blooms along the coasts of Somalia and Oman [Honjo et al., 1999]. The SW monsoon produces little productivity in the eastern Arabian Sea [Naidu and Malmgren, 1999]. In contrast, winter monsoon winds largely suppress upwelling in the west and north, but result in moderate upwelling off Central India [Colborn, 1975; Dueing and Koske, 1967; Schott and McCreary, 2001].

\footnotetext{
${ }^{1}$ Department of Geology, Banaras Hindu University, Varanasi, India.

${ }^{2}$ School of GeoSciences, Grant Institute, University of Edinburgh, King's Buildings, Edinburgh, UK.

${ }^{3}$ Department of Earth and Ocean Sciences, University of British Columbia, Vancouver, British Columbia, Canada.

Copyright 2011 by the American Geophysical Union. 0883-8305/11/2009PA001923
}

[3] This complex spatial pattern of productivity variations in the modern Arabian Sea in response to monsoon winds implies that the history of productivity may be different depending on geographic location. Previous studies using sediment cores from western and northern locations in the Arabian Sea [Anderson and Prell, 1993; Gupta et al., 2003; Ivanochko et al., 2005; Jung et al., 2002, 2004; Kroon et al., 1991a, 1991b; Naidu and Malmgren, 1996; Reichart et al., 1997; Schulz et al., 1998; Sirocko et al., 1993] show that upwelling-induced productivity, driven by SW (summer) monsoon winds, was reduced during the glacial period, specifically during the glacial North Atlantic Heinrich events.

[4] Upwelling-induced productivity in the eastern Arabian Sea possibly responded differently to climate change, e.g., monsoonal wind systems, during North Atlantic Heinrich events as a result of local atmospheric and oceanographic dynamics. Here, productivity is more likely to be influenced by the NE (winter) monsoon winds than the SW (summer) monsoon winds as the NE (winter) monsoon winds may have strengthened during Heinrich events [e.g., Kutzbach and Guetter, 1986].

[5] We use sediments from the eastern Arabian Sea to document the upwelling-induced productivity response during the North Atlantic Heinrich events, and to test the 


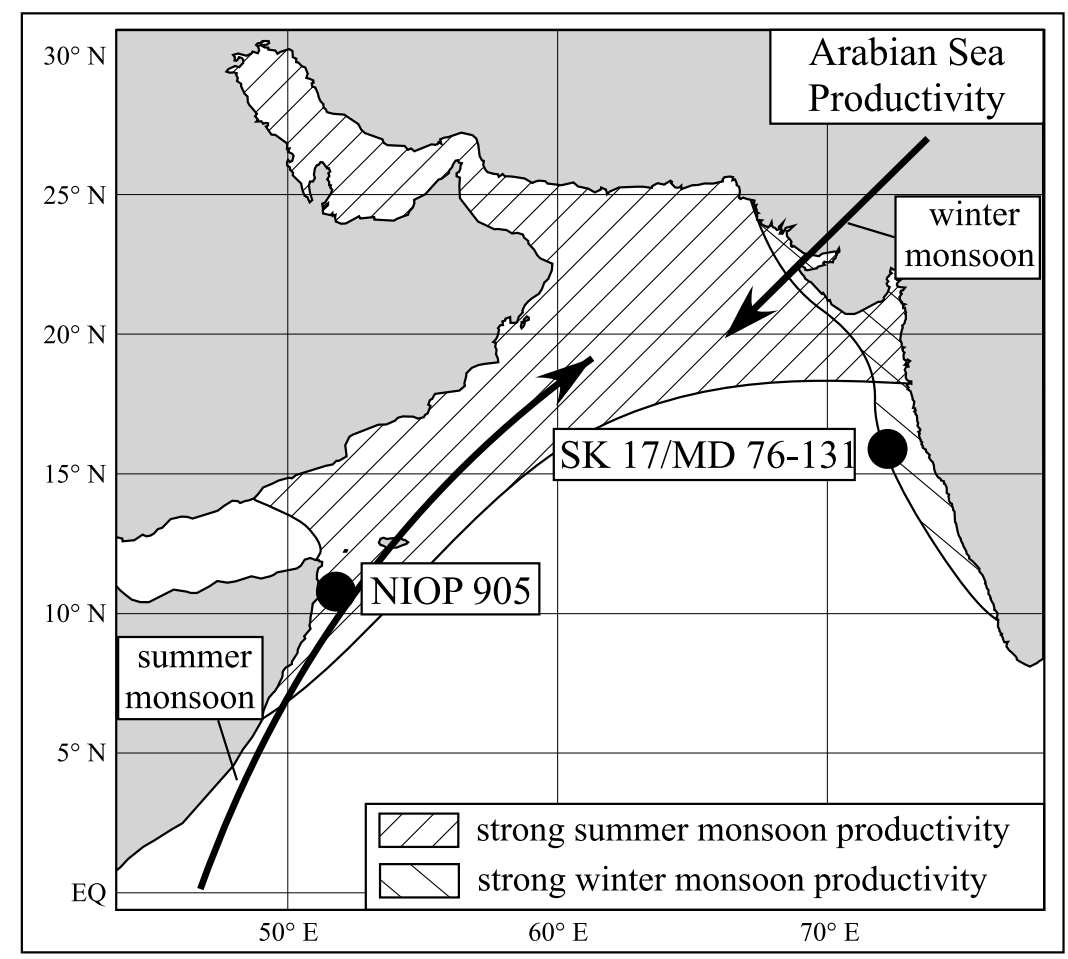

Figure 1. Core locations in the Arabian Sea. Areas predominantly reflecting summer and winter monsoon-driven upwelling are hatched.

hypothesis that NE (winter) monsoon winds potentially strengthened during these events. Boreal cold air masses may have descended onto the eastern Arabian Sea surface waters [Emeis et al., 1995; Kutzbach and Guetter, 1986], resulting in strengthened NE (winter) winds and increased upwelling and/or vertical mixing, both of which bringing up nutrients to fuel phytoplankton blooms.

\section{Methodology}

[6] Piston core (MD76-131) was collected in 1976 by the Marion Dufresne from the continental slope near Goa $\left(15^{\circ} 31.8^{\prime} \mathrm{N} ; 72^{\circ} 34.1^{\prime} \mathrm{E}\right)$ at a water depth of $1230 \mathrm{~m}$. Gravity core (SK 17) was collected from a nearby location $\left(15^{\circ} 15^{\prime} \mathrm{N}\right.$; $\left.72^{\circ} 58^{\prime} \mathrm{E}\right)$ at a water depth of $640 \mathrm{~m}$ by the Sagar Kanya in 1999 (Figure 1). Both cores were subsampled at 1-2 cm intervals allowing reconstruction of millennial-scale changes through time.

[7] Planktonic foraminiferal faunal composition was determined from $>125 \mu \mathrm{m}$ size fractions. Census counts were made on split samples containing approximately 300 specimens. Based on the census data, percentage abundance of each species was calculated.

[8] Planktonic foraminifera respond strongly to seasonal upwelling. Plankton net and sediment trap samples from the modern western Arabian Sea show large seasonal variations in the shell flux and species composition [Conan and Brummer, 2000; Kroon, 1991]. During the SW monsoon shell flux massively increases in response to upwelling. This shell flux is dominated by species such as Globigerina bulloides, Globigerina falconensis, Globigerinita glutinata, and Neogloboquadrina dutertrei, while other species respond in a more subdued manner. These species respond strongly to eutrophic waters, and are therefore termed "fertile" species. We have combined the relative abundances of these species as a percentage of the total assemblage to document variability in past productivity [Bé and Tolderlund, 1971; Brummer and Kroon, 1988; Vergnaud-Grazzini et al., 1995]. In addition, the ratio of Globigerina bulloides versus Globigerinoides ruber is used as a proxy for past productivity, where the former represents eutrophic and the latter oligotrophic waters, i.e., upwelling and/or vertical mixing versus stratification of the water column. This proxy is useful because it has been shown to respond strongly to Arabian Sea upper water column conditions in a western Arabian Sea sediment trap experiment [Conan and Brummer, 2000]. Values of 0.1 in the G. bulloides/G. ruber record reflect complete stratification, values of $0.3-1$ represent vertical mixing and/ or weak upwelling, values of $>1$ indicate moderate to strong upwelling (see Figure 2). Another advantage of this ratio is that it is less prone to dissolution artifacts on the seafloor or in the sediments, because both species are equally influenced by this process (see discussion).

[9] Total carbon concentration was determined by flashcombustion gas chromatography on a $\mathrm{C} / \mathrm{N}$ elemental analyzer using standard techniques. The $1 \sigma$ relative standard deviation (RSD) of measurements was $1.25 \%$. Carbonate carbon was determined by coulometry after acid evolution of $\mathrm{CO}_{2}$ with a precision of $3 \%(1 \sigma \mathrm{RSD})$, and $\mathrm{C}_{\text {org }}$ calculated from the difference (total carbon - carbonate carbon) with a combined precision of $3.3 \%$ ( $1 \sigma \mathrm{RSD})$.

\section{Composite Record and Age Model}

[10] Independent age models were constructed for each core based on a series of $\mathrm{AMS}^{14} \mathrm{C}$ dates ( 7 and 26 strati- 


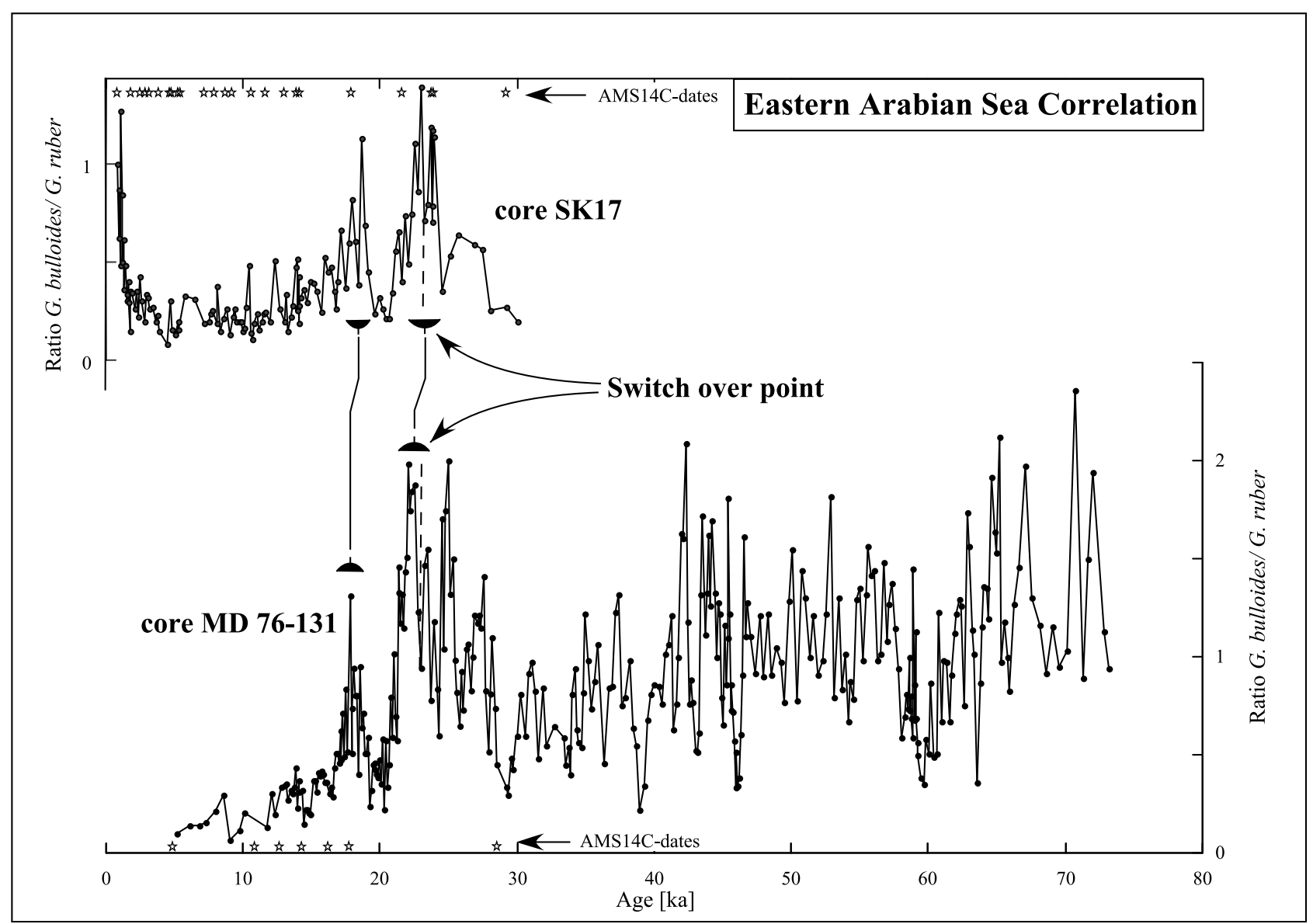

Figure 2. Splicing of cores MD76-131 and core SK 17. The G. bulloides/G.ruber ratios are given for core MD76-131 and SK 17. Asterisks mark AMS ${ }^{14} \mathrm{C}$-dated sections in the individual cores. On the basis of the highly similar pattern in the overlapping parts of the cores, a switchover point was defined to splice both records. The G. bulloides/G. ruber record is highly similar to the record of fertile species in Figure 4.

graphic levels were used for cores MD76-131 and SK 17, respectively; Table 1). The $\delta^{18} \mathrm{O}$ and $\delta^{15} \mathrm{~N}$ records were originally used as a guide for selecting levels of core depth for radiocarbon dating. The AMS radiocarbon dates were measured on monospecific samples (Globigerinoides ruber, white variety). $\mathrm{AMS}^{14} \mathrm{C}$ ages were converted to calendar ages based on the Calib 4.4 software package using the marine 98 calibration data set and a reservoir age of 640 years for the locations near Goa [Southon et al., 2002]. Previous studies demonstrated an in-phase relation of monsoonal change in the Arabian Sea and climate changes in Greenland ice cores [Ivanochko et al., 2005; Schulz et al., 1998]. Based on these findings, ages of core MD76-131 beyond $30 \mathrm{ka}$ B.P. were constrained by aligning the monsoon record of core MD76-131 (oscillations in the nitrogen isotope record) with Greenland ice core temperature excursions (stable oxygen isotope record of the GISP 2 ice core; Figure 3 ). In both cores, the G. bulloides/G. ruber records are highly similar within the $\mathrm{AMS}^{14} \mathrm{C}$-dated intervals (Figure 3 ). We use the G. bulloides/ G. ruber ratio records to splice both records into a composite record (Figure 2). This composite record correlates very well with the Greenland temperature record, and this correlation supports an in-phase relationship, within the uncertainty of the radiocarbon dating method, between climate events recorded in Greenland and the eastern Arabian Sea. In the remainder of the paper we refer to the composite record as core MD76-131/SK17.

\section{Results}

[11] The three proxy profile records of core MD76-131/ SK17 indicate similar productivity variations throughout the last 80 kyr B.P., with higher values prevailing during the glacial period than during the Holocene epoch (Figure 4). In addition, the records show rapid fluctuations throughout the last glacial period. The long-term changes in organic carbon content, fertile species abundance and G. bulloides/G. ruber profiles in the eastern Arabian Sea are driven by orbitally controlled variations in solar insolation. Specifically, insolation changes at the precessional frequency band largely dominate in the records and result in antiphase relations of the eastern Arabian Sea records and summer insolation change (Figure 4). For example, maximum productivity occurred off Goa (core MD76-131/SK17) throughout the last glacial maximum (around 18-22 ka B.P.). An opposite 
Table 1. $\mathrm{AMS}^{14} \mathrm{C}$ Dates for Core SK 17 and Core MD76-131

\begin{tabular}{|c|c|c|c|}
\hline Depth $(\mathrm{cm})$ & ${ }^{14} \mathrm{C}$ Age & Error $( \pm)$ & Calendar Age (kyr) \\
\hline \multicolumn{4}{|c|}{ Radiocarbon Dates Used for SK 17 Chronology } \\
\hline 1.5 & 1.524 & 0.068 & 0.875 \\
\hline 32.5 & 2.441 & 0.045 & 1.856 \\
\hline 40.5 & 2.96 & 0.045 & 2.498 \\
\hline 46.5 & 3.334 & 0.046 & 2.922 \\
\hline 50.5 & 3.494 & 0.046 & 3.149 \\
\hline 54.5 & 3.908 & 0.046 & 3.634 \\
\hline 60.5 & 4.093 & 0.047 & 3.875 \\
\hline 66.5 & 4.688 & 0.047 & 4.694 \\
\hline 70.5 & 4.775 & 0.048 & 4.8 \\
\hline 74.5 & 5.146 & 0.052 & 5.302 \\
\hline $76.5^{\mathrm{a}}$ & 5.121 & 0.048 & 5.269 \\
\hline 80.5 & 5.172 & 0.049 & 5.34 \\
\hline 90.5 & 6.873 & 0.052 & 7.216 \\
\hline 101 & 7.689 & 0.054 & 7.949 \\
\hline 117 & 8.451 & 0.058 & 8.764 \\
\hline 125 & 8.885 & 0.059 & 9.24 \\
\hline 169 & 10.068 & 0.061 & 10.657 \\
\hline 193 & 10.771 & 0.065 & 11.668 \\
\hline 209 & 11.639 & 0.070 & 12.983 \\
\hline 237 & 12.59 & 0.142 & 13.936 \\
\hline 261 & 12.803 & 0.087 & 14.171 \\
\hline 321 & 15.678 & 0.099 & 17.939 \\
\hline 381 & 18.87 & 0.132 & 21.61 \\
\hline 417 & 21.05 & 0.152 & 23.74 \\
\hline 433 & 21.91 & 0.221 & 23.886 \\
\hline 469 & 25.56 & 0.231 & 29.168 \\
\hline \multicolumn{4}{|c|}{ Radiocarbon Dates Used For Core MD76-131 Chronology } \\
\hline 9 & 4.146 & 0.35 & 3.986 \\
\hline 68 & 10.142 & 0.36 & 10.781 \\
\hline 103 & 11.246 & 0.39 & 12.632 \\
\hline 140 & 12.799 & 0.44 & 14.211 \\
\hline $154^{\mathrm{c}}$ & 12.405 & 0.39 & 13.647 \\
\hline 174 & 14.118 & 0.41 & 16.173 \\
\hline 204 & 15.425 & 0.65 & 17.681 \\
\hline 360 & 24.732 & 0.86 & 28.41 \\
\hline
\end{tabular}

${ }^{\mathrm{a}}$ Within error, not used for the chronology.

${ }^{\mathrm{b}}$ Adopted from Ivanochko [2005].

${ }^{\mathrm{c}}$ Age reversal, therefore not used for chronology.

relationship between insolation forcing and long-term productivity change was found in the western and northern Arabian Sea during the last glacial maximum (Figure 4) [Clemens et al., 1991; Ivanochko et al., 2005].

[12] While this overall line of reasoning with regard to glacial-interglacial change is justified over the last roughly $22 \mathrm{kyr}$, a closer inspection of Figure 4 also reveals subtle differences in amplitude and timing of productivity changes at the orbital time scale. These discrepancies probably reflect minor differences in proxy-specific sensitivities, recording slightly different aspects of monsoonal change possibly combined with lead-lag relations of changes in the (Asian) monsoon system [Clemens et al., 1991, 2010; Weber and Tuenter, 2011; Ziegler et al., 2010, and references therein]. Resolving the reasons for such lead-lag relationships at the orbital timescale, however, is beyond the scope of this paper, where the focus is on paleoproductivity change at the millennial timescale.

[13] The long-term productivity changes are punctuated by millennial-scale events. Despite subtle differences in amplitude in the various proxy records, prominent minima in all paleoproductivity records robustly occur in phase with Heinrich events (H1-6, peak ice surge events in the North
Atlantic; Figure 4), and with minima in the productivity record from the western Arabian Sea (Figure 4).

\section{Discussion}

[14] The results from eastern Arabian Sea core MD76131/SK17 provide valuable insights into the short- and long-term monsoon controlled productivity history in the region. In order to assess the gravity of our results two questions are crucial. The first question relates to the proxy records and how well the proxies used in this study reflect productivity variations, e.g., were there secondary effects on the proxy records? The second question relates to the interpretation of the paleoproductivity and how significant our observations are with respect to separating out summer versus winter monsoonal influence in controlling local productivity through time.

\subsection{Robustness of the Productivity Interpretations}

[15] We have used the combination of organic carbon concentrations and abundance changes of selected planktonic foraminiferal species to minimize uncertainties in our paleoproductivity reconstructions. Past productivity change is expected to result in consistent changes between these proxy records. Secondary effects, however, may have a proxyspecific impact on the productivity time series, resulting in deviating proxy records. For instance, organic carbon content of sediments is a quantitative measure of past productivity in the surface ocean, but secondary processes such as oxygen-dependent organic matter degradation and dilution by terrestrial sediments occasionally affect it [Ganeshram et al., 1999; Narayana et al., 2009]. The relative abundance of specific species, such as those from the group of fertile species (see above) or the G. bulloides/G. ruber ratio is largely independent of oxygenation and sediment dilution. That the paleoproductivity profiles, i.e., organic carbon content, fertile species concentration, and the G. bulloides/ G. ruber ratio of core MD76-131/SK17 vary largely in concert throughout (Figure 4) demonstrates that the three paleoproductivity profiles are responding to a common control which is the primary productivity signal. This finding is particularly clear in all paleoproductivity records at the millennial scale. All proxy records show significant declines in productivity during the North Atlantic Heinrich events.

[16] It could be argued, however, that carbonate dissolution has affected the record of core MD76-131/SK17. If for example the more fragile species from the group of fertile planktonic foraminifera were preferentially removed by dissolution, the resulting fertile species record would not depict variations in surface ocean productivity-driven changes in foraminifera flux. Obviously, selective preservation may create a predicament for many study sites around the globe. Selective preservation, however, can be dismissed to have influenced the fossil planktonic foraminiferal assemblages used in this study. The main argument for this rests on the downcore ratio of the planktonic foraminiferal species G. bulloides and G. ruber. Both species are roughly equally sensitive to carbonate dissolution [Berger, 1968; Conan et al., 2002; Cullen and Prell, 1984]. It is widely accepted that abundance variations in $G$. bulloides are overwhelmingly driven by changes in (seasonal) surface ocean productivity [e.g., Bé and Tolderlund, 1971; Conan and Brummer, 2000; 


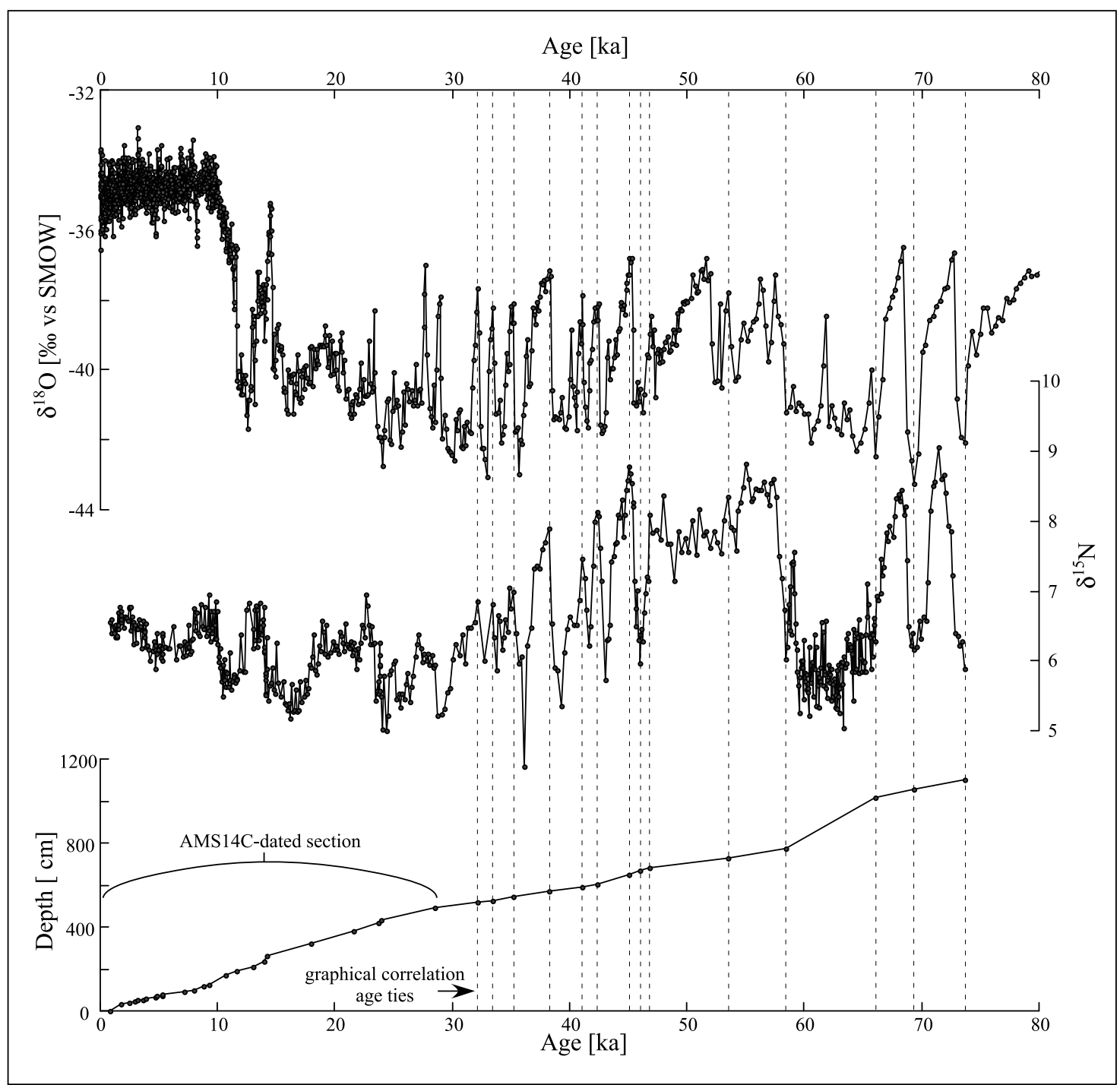

Figure 3. Age control and age/depth relation of core MD76-131/SK17. Stippled lines in the section older than $30 \mathrm{ka} \mathrm{B.P.} \mathrm{indicate} \mathrm{tie} \mathrm{points} \mathrm{used} \mathrm{to} \mathrm{align} \mathrm{the} \mathrm{record} \mathrm{of} \mathrm{core} \mathrm{MD76-131/SK17} \mathrm{to} \mathrm{the} \mathrm{GISP2} \mathrm{chronology}$ based on Blunier and Brook [2001], Blunier et al. [1998], and Meese et al. [1997].

Kroon, 1988, and references therein], whereas G. ruber abundances reflect the annual flux. Hence, the G. bulloides/ $G$. ruber ratio should reflect variations in local productivity [Conan and Brummer, 2000; Conan et al., 2002], similar to the abundance record of fertile species. Consequently, if dissolution had affected the fertile species record, we would expect a weak or no correlation between the G. bulloides/ $G$. ruber ratio and the fertile species data in the downcore record. Figure 4 clearly shows, however, that both records largely vary in tune. This finding strongly supports the notion that the fertile species record indeed overwhelmingly reflects surface ocean productivity and that carbonate dissolution did not significantly affect our data. Specifically, the observation of minima in productivity during the Heinrich events is robust.

[17] The rapid eastern Arabian Sea productivity fluctuations can be placed in perspective of modern seasonal productivity variability using the $G$. bulloides $/ G$. ruber ratio values in the composite sediment record (compare Figures 2 and 4). The top sediments show G. bulloides/G. ruber values of about 1 for the last $\sim 2 \mathrm{kyr}$, which implies moderate upwelling and/or vertical mixing in the eastern Arabian Sea, which agrees with modern observations in the area [Colborn, 1975; Dueing and Koske, 1967; Schott and McCreary, 2001].The highest ratios of 2-2.5 can be found in the glacial period, and these peaks have a tendency to relate specifically to the interstadial periods. Today, such high ratios occur in sediments underlying the seasonal upwelling cells of the western Arabian Sea [Conan and Brummer, 2000], and therefore indicate high productivity in line with the fertile species abundance profile and high organic carbon concentrations. The lowest G. bulloides/ $G$. ruber ratio values of $0.1-0.2$ are found during the North Atlantic Heinrich events and during most of the Holocene epoch (except for the last $\sim 2$ kyr). The lowest values generally coincide with low abundance values in the fertile species and organic carbon content profiles with few exceptions. Such low values are typical of stratification of 


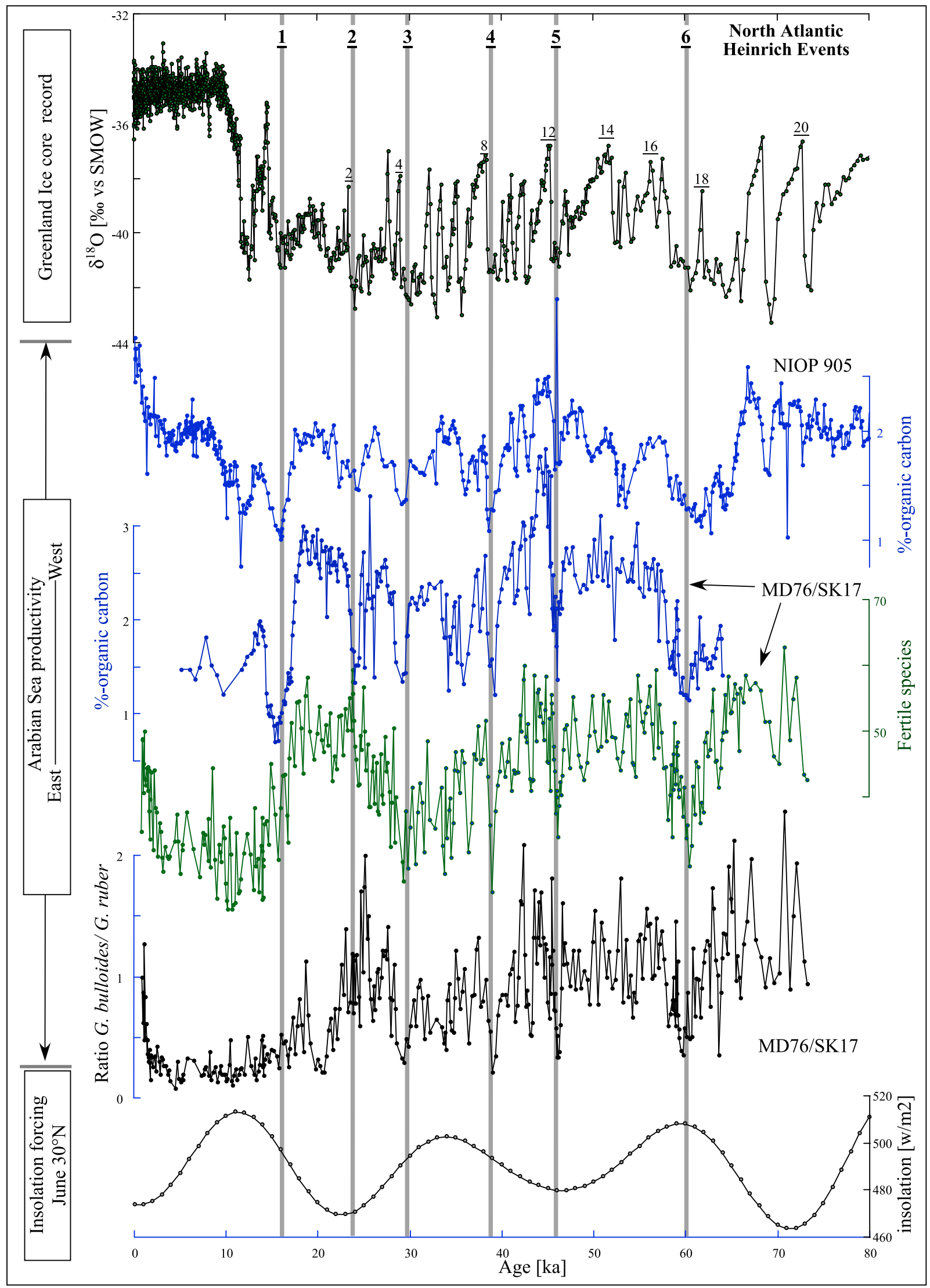

Figure 4 
the upper water column in the modern Arabian Sea, when winds are weak and fail to produce upwelling and vertical mixing analogous to intramonsoon periods. These low values in the G. bulloides/G. ruber proxy record from sediments show that the water column was stratified and associated productivity was low throughout the entire year. Any productivity during one of the seasons would have elevated the G. bulloides/G. ruber ratio values in the sediments to levels above those in the modern intramonsoonal period. Hence, the low values during the minimum peaks in the G. bulloides/G. ruber ratio occurring at maximum cold conditions in the North Atlantic strongly supports the notion that these periods represent episodes of extreme low productivity in the eastern Arabian Sea with no obvious effects of winds on productivity. Therefore, the seasonal aspect of wind-driven productivity was reduced.

\subsection{Summer Versus Winter Monsoonal Productivity (Interglacial-Glacial Scale)}

[18] The productivity increase in records of core MD76131/SK17 during the last glacial period is consistent with strong winter monsoons prevailing during periods of low summer insolation in agreement with computer simulations [Kutzbach and Guetter, 1986]. Despite the consistency of data and model results, it could be alternatively argued that stronger summer monsoon was still prevalent off Goa due to southward migration of the region influenced by the summer monsoonal airflow. Such a scenario envisions a weaker summer monsoon and productivity in the northern Arabian Sea (off Oman and Pakistan) but a stronger summer monsoon influence recorded in the sediments off Goa during glacial periods. This proposition also implies significant rainfall-induced runoff, resulting in lowered glacial sea surface salinities off Goa. This proposition, however, is not supported by recent findings that show that sea surface salinity values in the region were generally higher during glacial times [Banakar et al., 2010]. Higher salinity off Goa strongly argues against a pronounced long-term summer monsoon influence during the glacial period near the location of site MD76-131/SK17. Neither is there any evidence of a southern displacement of summer monsoon influence during the glacial in records located off Somalia (Core 905P) which also records lower summer monsoon influence during the glacial in both their productivity and salinity records [Anand et al., 2008; Ivanochko et al., 2005; Jung et $a l ., 2002]$. Therefore we conclude that the increased productivity recorded off Goa during glacial periods contrasts records off Somalia, Oman and Pakistan and should have resulted from stronger glacial winter monsoon winds.

\subsection{Millennial-Scale Monsoonal Change Across the Arabian Sea}

[19] At the millennial timescale the record of core MD76131/SK17 also shows that productivity off Goa was not uniformly high throughout the glacial period. Conspicuous drops in fertility punctuated the record and were most pronounced during Heinrich events 1-6. These drops were most likely caused by a reduction in stadial winter monsoon strengths given that the longer time scale trend of enhanced productivity during the glacial period at this site appears to have been influenced by the winter monsoon. This inference that glacial productivity variations recorded off Goa at the millennial time scale is related to variability in the winter monsoon is consistent with salinity records off Goa [Anand et al., 2008; Banakar et al., 2010]. These records show increased salinity during the glacial period relative to the Holocene, indicating weaker summer monsoon and run off throughout the last glacial period. However, salinity variations remained small throughout the last glacial cycle in contrast with large drop in productivity during stadial events (H1-6). Given that the winter monsoon is a scarce source of moisture, its variability is unlikely to be sensitively recorded in salinity changes, but is expected to influence more profoundly the productivity variations off Goa. Hence, available evidence strongly favors the view that the productivity records of core MD73-131/SK17 predominantly reflect winter monsoonal change during the last glacial cycle.

[20] It is likely that during interstadials the records of core MD73-131/SK17 reflect some summer monsoon-induced productivity, similar to the modern situation. With regard to stadial conditions, however, our data argue against any SW monsoonal influence because productivity and its seasonal variability were strongly diminished during stadials (see discussion above). The millennial-scale minima in eastern Arabian Sea productivity are in phase with similar minima in the western and northern Arabian Sea (core NIOP 905; Figure 4) [Ivanochko et al., 2005; Schulz et al., 1998]. Inter Tropical Convergence Zone (ITCZ) positioning likely affected summer monsoon-induced productivity in all these regions of the Arabian Sea. A weak summer monsoon in the Arabian Sea during northern hemisphere cold phases can be explained by a southward shift of the position of the ITCZ [Jung et al., 2002; Sirocko et al., 1991]. Such a shift would weaken the low-pressure cell over Tibet and continental India and therefore reduce summer monsoon strength, as portrayed by the minima in paleoproductivity in the northern and western Arabian Sea (Figure 4) [Altabet et al., 2002; Ivanochko et al., 2005; Schulz et al., 1998]. This view is supported by modeling results which also suggest a similar reduction in summer monsoon strength during stadials [Zhang and Delworth, 2005].

[21] Lowered nutrient levels in subsurface waters that upwell in the Arabian Sea could also explain the repeated reductions in productivity during Heinrich events. Such a scenario was recently proposed based on modeling results where reduced overturning circulation in the Atlantic Ocean results in reduced nutrient levels in the intermediate Indian Ocean during Heinrich events [Schmittner et al., 2007]. Although such a scenario cannot be excluded, it seems unlikely in the light of the evidence for warming of surface

Figure 4. Productivity variations in the Arabian Sea. The productivity records (organic carbon concentration, abundance of fertile species, and the G. bulloides/G. ruber ratio) for core MD76-131/SK17 from the eastern Arabian Sea are compared to the productivity changes off Somalia (organic carbon concentration from core NIOP 905 [Ivanochko et al., 2005]). The Greenland ice core (GISP2) record is given for reference [Blunier and Brook, 2001; Blunier et al., 1998; Meese et al., 1997]. The bottom record shows June insolation changes at $30^{\circ} \mathrm{N}$. Periods of the Heinrich events are marked by gray lines. 
ocean waters in the Arabian Sea during Heinrich events [Anand et al., 2008; Saher et al., 2007, 2009]. Documented warming of Arabian Sea surface waters during Heinrich events are consistent with reduced monsoon winds. The advocated reduction in monsoonal airflow would result in stratification and hence reduced upwelling of cold subsurface water, leading to higher surface ocean temperatures and reduced productivity at the sea surface. On the other hand, changes in nutrient levels in upwelled waters (without changes to upwelling intensity) will lead to reduced productivity but need not be accompanied by changes in surface temperatures.

[22] The millennial-scale variability of the eastern and the western Arabian Sea productivity records imply that both monsoon seasons are affected in the same way by northern hemisphere climate change. The eastern Arabian Sea fertile species and organic carbon concentration records both show high values during interstadials and low values during stadials. This relationship has been shown previously in records from the western and northern Arabian Sea (Figure 4) [Altabet et al., 2002; Ivanochko et al., 2005; Schulz et al., 1998], implying that the entire Arabian Sea biological production factory was switched on during interstadials and switched off during northern hemisphere stadial periods. Given the distinct summer monsoonal influence on productivity in the western and northern Arabian Sea and the winter monsoonal control on productivity in the eastern Arabian Sea, the records provide compelling evidence that there was a substantial decrease in West Asian monsoon strength, in both seasons, during northern hemisphere cold phases.

[23] With regard to our main finding, i.e., a synchronous summer and winter monsoon reduction across the Arabian Sea during stadial periods, it is somewhat difficult to put forward a physical mechanism that would explain the reduced winter monsoon influence in the Arabian Sea during these times. Applying the modern concepts of wind circulation over Eurasia and environmental controls on atmospheric pressure gradients, it can be argued that during extreme conditions in the northern hemisphere such as during Heinrich events, the polar cell in the North Atlantic sector was dramatically enhanced at the expense of the Hadley cell circulation. The pressure gradient in the rootregion of the Westerlies in the Atlantic sector would probably have increased and the center of the flow shifted to a position further south than it does in winter today. Such a perturbation would probably not only have shifted the Westerlies in the Atlantic sector to extreme southern locations, but would also have led to downstream changes in monsoonal airflow. In the modern world the Westerlies propagate around the globe as an alternation of north and southward meandering air masses of subtropical and polar origin, respectively. During maximum cold conditions occurring during Heinrich events the Westerlies in the Atlantic sector were probably displaced to an extreme southerly position. This expansion of polar air masses in the Atlantic region most likely pushed the downstream, northward penetrating meander further to the east. Aided by the control of wind flow exerted by the Himalayas, the relocated Westerly airflow would have "separated" the West Asian monsoon system from that in the East, allowing a strengthened winter monsoon to develop in East Asia [An, 2000; Lu et al., 2000; Porter and An, 1995; Yancheva et al., 2007], whereas it was weakened in the Arabian Sea. Both, an increased temperature gradient between Siberia and the North Pacific Ocean and a free airflow between these regions support the idea of a strengthened East Asian winter monsoon during stadials. In contrast, a stronger westerly airflow over the Arabian Sea weakened the winter monsoon northeasterly winds here, resulting in the obviously reduced upwelling as observed off central India.

[24] We conclude that at the millennial timescale the entire Arabian Sea biological production factory switched off during stadials as a result of coeval summer and winter monsoon breakdowns. The simultaneous change in productivity across the Arabian Sea would have had consequences for the stability of the oxygen minimum zone and the carbon cycling in the area. In addition, our findings support the notion that East and West Asian monsoons evolved differently during cold periods in the North Atlantic region. Additional research is required to further substantiate this conclusion.

[25] Acknowledgments. We thank four anonymous referees for their constructive reviews that have helped to improve the manuscript. We also thank the shipboard teams of the Marion Dufresne and the Sagar Kanya for sampling core locations MD76-131 and SK17, respectively. We thank Michel Fontugne, CNRS France, for providing samples from Core MD76-131. Work was supported by funding to A.D.S. from the DST grant SR/S4/ES-30/2002, the GBP-ISRO (India), and the Royal Society India-UK Science Network Scheme. AMS ${ }^{14} \mathrm{C}$ dates were funded by the Natural Environment Research Council (allocation 924.0501) and provided by the NERC Radiocarbon Laboratory, East Kilbride, United Kingdom. This research was supported by a standard grant from the Natural Environment Research Council of the United Kingdom to R. Ganeshram and an ORSAS Ph.D. fellowship to T. Ivanochko.

\section{References}

Altabet, M. A., M. J. Higginson, and R. W. Murray (2002), The effect of millennial-scale changes in the Arabian Sea denitrification on atmospheric $\mathrm{CO}_{2}$, Nature, 415, 159-162, doi:10.1038/415159a

An, Z. (2000), The history and variability of the East Asian paleomonsoon climate, Quat. Sci. Rev., 19, 171-187, doi:10.1016/S0277-3791(99) 00060-8.

Anand, P., D. Kroon, A. D. Singh, R. Ganeshram, G. Ganssen, and H. Elderfield (2008), Coupled sea surface temperature-seawater $\delta^{18} \mathrm{O}$ reconstructions in the Arabian Sea at the millennial scale for the last 35 ka, Paleoceanography, 23, PA4207, doi:10.1029/2007PA001564.

Anderson, D. M., and W. L. Prell (1993), A $300 \mathrm{kyr}$ record of upwelling off Oman during the late Quaternary; evidence of the Asian southwest monsoon, Paleoceanography, 8, 193-208, doi:10.1029/93PA00256.

Banakar, V. K., B. S. Mahesh, G. Burr, and A. R. Chondakar (2010), Climatology of the Eastern Arabian Sea during the last glacial cycle reconstructed from paired measurement of foraminiferal $\delta^{18} \mathrm{O}$ and $\mathrm{Mg} / \mathrm{Ca}$, Quat. Res., 73, 535-540, doi:10.1016/j.yqres.2010.02.002.

Banse, K., and C. R. McClain (1986), Satellite-observed winter blooms of phytoplankton in the Arabian Sea, Mar. Ecol. Prog. Ser., 34, 201-211, doi:10.3354/meps034201.

Bauer, S., G. L. Hitchkock, and D. B. Olson (1991), Influence of monsoonally forced Ekman dynamics upon surface layer depth and plankton biomass distribution in the Arabian Sea, Deep Sea Res., Part A, 38, 531-553, doi:10.1016/0198-0149(91)90062-K.

Bé, A. W. H., and D. S. Tolderlund (1971), Distribution and ecology of living planktonic foraminifera in surface waters of the Atlantic and Indian Oceans, in The Micropaleontology of Oceans, edited by B. M. Funnell and W. R. Riedel, pp. 105-149, Cambridge Univ. Press, Cambridge, U. K. Berger, W. H. (1968), Planktonic foraminifera: Selective solution and paleoclimatic interpretation, Deep Sea Res. Oceanogr. Abstr., 15, 31-43, doi:10.1016/0011-7471(68)90027-2. 
Blunier, T., and E. J. Brook (2001), Timing of millennial-scale climate change in Antarctica and Greenland during the last glacial period, Science, 291, 109-112, doi:10.1126/science.291.5501.109.

Blunier, T., et al. (1998), Asynchrony of Antarctic and Greenland climate change during the last glacial period, Nature, 394, 739-743, doi:10.1038/ 29447.

Brummer, G. J. A., and D. Kroon (1988), Planktonic foraminifers as tracers of ocean-climate history, Ph.D. thesis, 346 pp, Free Univ., Amsterdam. Clemens, S., W. L. Prell, D. Murray, G. B. Shimmield, and G. P. Weedon (1991), Forcing mechanisms of the Indian Ocean monsoon, Nature, 353, 720-725, doi:10.1038/353720a0.

Clemens, S. C., W. L. Prell, and Y. Sun (2010), Orbital-scale timing and mechanisms driving Late Pleistocene Indo-Asian summer monsoons: Reinterpreting cave speleothem $\delta^{18} \mathrm{O}$, Paleoceanography, 25, PA4207, doi:10.1029/2010PA001926.

Colborn, J. G. (1975), The Thermal Structure of the Indian Ocean, Int Indian Ocean Exped. Monogr., vol. 2, 173 pp., Univ. of Hawaii Press, Honolulu.

Conan, S. M. H., and G.-J. Brummer (2000), Fluxes of planktonic Foraminifera in response to monsoonal upwelling on the Somalia Basin margin, Deep Sea Res., Part II, 47, 2207-2227, doi:10.1016/S0967-0645(00) 00022-9.

Conan, S. M. H., E. Ivanova, and G.-J. A. Brummer (2002), Quantifying carbonate dissolution and calibration of foraminiferal dissolution indices in the Somali Basin, Mar. Geol., 182, 325-349, doi:10.1016/ S0025-3227(01)00238-9.

Cullen, J. L., and W. L. Prell (1984), Planktonic foraminifera of the northern Indian Ocean; distribution and preservation in surface sediments, Mar. Micropaleontol., 9, 1-52, doi:10.1016/0377-8398(84)90022-7.

Dueing, W., and P. H. Koske (1967), Hydrographic observation in the Arabian Sea during the N.E. monsoon period 1964-1965, Meteor Forschungsergeb., Reihe A, 8, 1-43.

Emeis, K. C., D. M. Anderson, H. Doose, D. Kroon, and D. Schulz-Bull (1995), Sea-surface temperatures and the history of monsoon upwelling in the Northwest Arabian Sea during the last 500,000 years, Quat. Res., 43(3), 355-361, doi:10.1006/qres.1995.1041.

Ganeshram, R., S. E. Calvert, T. F. Pedersen, and G. Cowie (1999), Factors controlling the burial of organic carbon in laminated and bioturbated sediments off NW Mexico: Implications for hydrocarbon preservation, Geochim. Cosmochim. Acta, 63, 1723-1734, doi:10.1016/S0016-7037(99) 00073-3

Gupta, A. K., D. M. Anderson, and J. T. Overpeck (2003), Abrupt changes in the Asian southwest monsoon during the Holocene and their links to the North Atlantic Ocean, Nature, 421, 354-357, doi:10.1038/ nature 01340 .

Honjo, S., J. Dymond, W. L. Prell, and V. Ittekkot (1999), Monsooncontrolled export fluxes to the interior of the Arabian Sea, Deep Sea Res., Part II, 46, 1859-1902, doi:10.1016/S0967-0645(99)00047-8.

Ivanochko, T. S. (2005), Sub-orbital variations in the intensity of the Arabian Sea monsoon, Ph.D. thesis, 230 pp., Univ. of Edinburgh, Edinburgh, U. K.

Ivanochko, T. S., R. S. Ganeshram, G.-J. A. Brummer, G. Ganssen, S. J. A Jung, S. G. Moreton, and D. Kroon (2005), Variations in tropical convection as an amplifier of global climate change at the millennial scale, Earth Planet. Sci. Lett., 235, 302-314, doi:10.1016/j.epsl.2005.04.002.

Jung, S. J. A., G. R. Davies, G. M. Ganssen, and D. Kroon (2002), Centennialmillennial scale monsoon variations off Somalia over the last $35 \mathrm{kyr}$, in Tectonic and Climatic Evolution of the Arabian Sea Region, edited by P. Clift and D. Kroon, Geol. Soc. Spec. Publ., 195, 341-352.

Jung, S. J. A., G. R. Davies, G. M. Ganssen, and D. Kroon (2004), Synchronous Holocene sea surface temperature and rainfall variations in the Asian monsoon system, Quat. Sci. Rev., 23, 2207-2218, doi:10.1016/j. quascirev.2004.08.009.

Kroon, D. (1988), The planktic $\delta^{13} \mathrm{C}$ record, upwelling and climate, in Planktonic Foraminifers as Tracers of Ocean-Climate History, edited by G.-J. A. Brummer and D. Kroon, pp. 335-346, Free Univ. Press, Amsterdam.

Kroon, D. (1991), Distribution of extant planktic foraminiferal assemblages in Red Sea and northern Indian Ocean surface waters, Rev. Esp. Micropaleontol., 23(1), 37-74.

Kroon, D., T. N. F. Steens, and S. R. Troelstra (1991a), Onset of monsoonal related upwelling in the western Arabian Sea as revealed by planktonic foraminifers, in Oman Margin/Neogene Package, Proc. Ocean Drill. Program Sci. Results, 117, 257-263.

Kroon, D., K. Beets, S. Mowbray, G. B. Shimmield, and T. N. F. Steens (1991b), Changes in northern Indian Ocean monsoonal wind activity during the last 500KA, Mem. Soc. Geol. Ital., 44, 189-207.

Kutzbach, J. E., and P. J. Guetter (1986), The influence of changing orbita parameters and surface boundary conditions on climate simulations for the past 18.000 years, J. Atmos. Sci., 43, 1726-1759, doi:10.1175/ 1520-0469(1986)043<1726:TIOCOP $>2.0$. CO;2.

Lu, H., K. van Huissteden, J. Zhou, J. Vandenberghe, X. Liu, and P.-P. Qi (2000), Variability of East Asian winter monsoon in quaternary climatic extremes in north China, Quat. Res., 54, 321-327, doi:10.1006/ qres.2000.2173.

Meese, D. A., A. J. Gow, R. B. Alley, G. A. Zielinski, P. M. Grootes, M. Ram, K. C. Taylor, P. A. Mayewski, and J. F. Bolzan (1997), The Greenland Ice Sheet Project 2 depth-age scale: Methods and results, J. Geophys. Res., 102, 26,411-26,423, doi:10.1029/97JC00269.

Naidu, P. D., and B. A. Malmgren (1996), Relationship between late Quaternary upwelling history and coiling properties of Neogloboquadrina pachyderma and Globigerina bulloides in the Arabian Sea, J. Foraminiferal Res., 26(1), 64-70, doi:10.2113/gsjfr.26.1.64.

Naidu, P. D., and B. A. Malmgren (1999), Quaternary carbonate record from the equatorial Indian Ocean and its relationship with productivity changes, in Aspects of Geology, Geophysics and Paleoceanography of the Indian Ocean: Selected papers, edited by A. S. Naidu and R. C. Madhusudana, pp. 49-62, Elsevier, Amsterdam.

Narayana, A. C., P. D. Naidu, N. Shinu, P. Nagabhushanam, and B. S Sukjija (2009), Carbonate and organic carbon content changes over last $20 \mathrm{ka}$ in the Southeastern Arabian Sea: Paleoceanographic implications, Quat. Int., 206, 72-77, doi:10.1016/j.quaint.2008.10.010.

Porter, S. C., and Z. An (1995), Correlation between climate events in the North Atlantic and China during the last glaciation, Nature, 375, 305-308, doi:10.1038/375305a0.

Reichart, G. J., M. den Dulk, H. J. Visser, C. H. van der Weijden, and W. J. Zachariasse (1997), A 225 kyr record of dust supply, paleoproductivity and the oxygen minimum zone from the Murray Ridge (northern Arabian Sea), Palaeogeogr. Palaeoclimatol. Palaeoecol., 134(1-4), 149-169, doi:10.1016/S0031-0182(97)00071-0.

Saher, M. H., S. J. A. Jung, H. Elderfield, M. J. Greaves, and D. Kroon (2007), Sea surface temperatures of the western Arabian Sea during the last deglaciation, Paleoceanography, 22, PA2208, doi:10.1029/ 2006PA001292.

Saher, M. H., F. Rostek, S. J. A. Jung, E. Bard, R. R. Schneider, M. Greaves, G. M. Ganssen, H. Elderfield, and D. Kroon (2009), Western Arabian Sea SST during the penultimate interglacial: A comparison of $\mathrm{U}_{37}^{\mathrm{K}}$ and $\mathrm{Mg} / \mathrm{Ca}$ paleothermometry, Paleoceanography, 24, PA2212, doi:10.1029/ 2007PA001557.

Schmittner, A., E. D. Galbraith, S. W. Hostetler, and T. F. Pedersen (2007), Large fluctuations of dissolved oxygen in the Indian and Pacifc Oceans during Dansgaard-Oeschger oscillations caused by variations of North Atlantic Deep Water subduction, Paleoceanography, 22, PA3207, doi:10.1029/2006PA001384.

Schott, F. A., and J. P. J. McCreary (2001), The monsoon circulation of the Indian Ocean, Prog. Oceanogr., 51, 1-123, doi:10.1016/S0079-6611(01) 00083-0.

Schulz, H., U. von Rad, and H. Erlenkeuser (1998), Correlation between Arabian Sea and Greenland climate oscillation of the past 110,000 years, Nature, 393, 54-57.

Sirocko, F., M. Sarnthein, H. Lange, and H. Erlenkeuser (1991), Atmospheric summer circulation and coastal upwelling in the Arabian Sea during the Holocene and the last glaciation, Quat. Res., 36(1), 72-93, doi:10.1016/0033-5894(91)90018-Z

Sirocko, F., M. Sarnthein, H. Erlenkeuser, H. Lange, M. Arnold, and J. C. Duplessy (1993), Century-scale events in monsoonal climate over the past 24,000 years, Nature, 364, 322-324, doi:10.1038/364322a0.

Southon, J. R., M. Kashgarian, M. R. Fontugne, B. Metivier, and W. Yim (2002), Marine reservoir corrections for the Indian Ocean and southeast Asia, Radiocarbon, 44, 167-180.

Vergnaud Grazzini, C., M. T. Vénec-Peyré, J. P. Caulet, and N. Lerasle (1995), Fertility tracers and monsoon forcing at an equatorial site of the Somali basin (Northwest Indian ocean), Mar. Micropaleontol., 26, 137-152, doi:10.1016/0377-8398(95)00070-4.

Weber, N., and E. Tuenter (2011), The impact of varying ice sheets and greenhouse gases on the intensity and timing of boreal summer monsoons, Quat. Sci. Rev., 30, 469-479, doi:10.1016/j.quascirev.2010.12.009.

Wyrtki, K. (1974), Physical oceanography of the Indian Ocean, Contrib. Hawaii Inst. Geophys., 483(3), 202-220.

Yancheva, G., N. R. Nowaczyk, J. Mingram, P. Dulski, G. Schettler, J. Negendank, J. Liu, D. M. Sigman, L. C. Peterson, and G. H. Haug (2007), Influence of the intertropical convergence zone on the East Asian monsoon, Nature, 445, doi:10.1038/nature05431.

Zhang, R., and T. L. Delworth (2005), Simulated Tropical Response to a Substantial Weakening of the Atlantic Thermohaline Circulation, J. Clim. 18, 1853-1860, doi:10.1175/JCLI3460.1.

Ziegler, M., L. J. Lourens, E. Tuenter, F. Hilgen, G.-J. Reichart, and N. Weber (2010), Precession phasing offset between Indian summer 
monsoon and Arabian Sea productivity linked to changes in Atlantic overturning circulation, Paleoceanography, 25, PA3213, doi:10.1029/ 2009PA001884.

K. Darling, R. Ganeshram, S. J. A. Jung, and D. Kroon, School of GeoSciences, Grant Institute, University of Edinburgh, King's Buildings, West Mains Road, Edinburgh EH9 3JW, UK. (simon.jung@ed.ac.uk)
T. Ivanochko, Department of Earth and Ocean Sciences, University of British Columbia, EOS South Rm. 152, Vancouver, BC V6T 1Z4, Canada.

A. D. Singh, Department of Geology, Banaras Hindu University, Varanasi, Uttar Pradesh 221 005, India. 